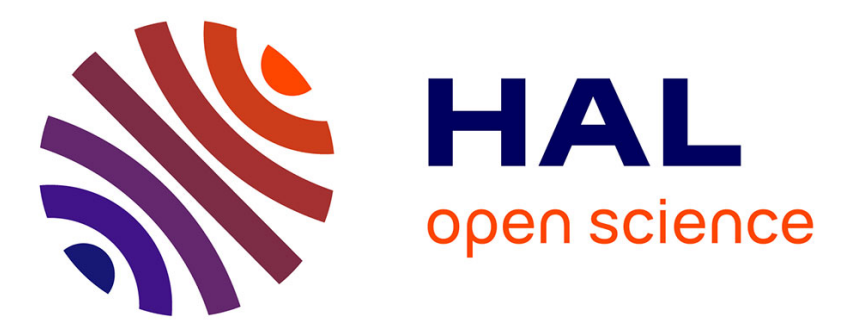

\title{
Factors associated with non-return to work in the severely injured victims 3 years after a road accident: A prospective study
}

Carole Pelissier, Emmanuel Fort, Luc Fontana, Barbara Charbotel, Martine Hours

\section{To cite this version:}

Carole Pelissier, Emmanuel Fort, Luc Fontana, Barbara Charbotel, Martine Hours. Factors associated with non-return to work in the severely injured victims 3 years after a road accident: A prospective study. Accident Analysis \& Prevention, 2017, 106, pp. 411-419. 10.1016/j.aap.2017.06.020 . hal01598100

\section{HAL Id: hal-01598100 \\ https://hal.science/hal-01598100}

Submitted on 9 Oct 2017

HAL is a multi-disciplinary open access archive for the deposit and dissemination of scientific research documents, whether they are published or not. The documents may come from teaching and research institutions in France or abroad, or from public or private research centers.
L'archive ouverte pluridisciplinaire $\mathbf{H A L}$, est destinée au dépôt et à la diffusion de documents scientifiques de niveau recherche, publiés ou non, émanant des établissements d'enseignement et de recherche français ou étrangers, des laboratoires publics ou privés. 
PELISSIER, Carole, FORT, Emmanuel, FONTANA, Luc, CHARBOTEL, Barbara, HOURS, Martine, 2017, Factors

associated with non-return to work in the severely injured victims 3 years after a road accident: A prospective study, Accident analysis and prevention, 106, Elsevier, pp. 411-419, DOI: 10.1016/j.aap.2017.06.020

\title{
Factors associated with non-return to work in the severely injured victims 3 years after a road accident: a prospective study
}

\section{Short Title: risk factors for non-return to work after a car crash}

\author{
C. Pélissier, MD PhD ${ }^{\mathrm{a}, \mathrm{b}}$, E. Fort $\mathrm{MSc}^{\mathrm{c}}$, L. Fontana MD PhD ${ }^{\mathrm{a}, \mathrm{b}}$, B. Charbotel MD \\ $\mathrm{PhD}^{\mathrm{c}, \mathrm{d}}$, M.Hours MD PhD
}

a Université de Lyon, Université Lyon 1, Université de St Etienne, IFSTTAR, UMRESTTE, UMR_T9405, 42005 Saint Etienne, France

${ }^{\mathrm{b}}$ Service de Santé au Travail, CHU de Saint-Etienne, France

c Université de Lyon, Université Lyon 1, IFSTTAR, UMRESTTE, UMR_T9405, F69373 Lyon, France

${ }^{\mathrm{d}}$ Hospices Civils de Lyon, Service de Santé au Travail,

e Univ Lyon, IFSTTAR, Univ Lyon 1, UMRESTTE, UMR_T9405, F-69675 Bron, France

Correspondence to: C. Pélissier, Tel.: +33 (0)477828325; fax: +33 (0)477828139; email: carole.pelissier@chu-st-etienne.fr

Key terms: prospective study; road accident casualties; seriously injured; risk factors; non-return to work 


\section{ABSTRACT}

Road accidents may impact victims' physical and/or mental health and sociooccupational life, particularly the capacity to return to work. The purpose of our study is to assess modifiable medical and socio-occupational factors of non-return to work in the severely injured 3 years after a road accident. Among 1,168 road accidents casualties in the Rhône administrative Département of France followed for five years, 141 of the 222 severely injured (Maximal Abbreviated Injury Scale $\geq 3$ ) aged more than 16 years who were in work at the time of the accident, reported whether they had returned to work in the 3 years following the accident. The subgroups of those who had $(n=113)$ and had not returned to work $(\mathrm{n}=28)$ were compared for socio-occupational (gender, age, educational level, marital status, socio-occupational group) accident-related medical factors (type of road user, type of journey, responsibility in the accident, initial care) and post-accident medical factors (pain intensity, post-traumatic stress disorder, physical sequelae, quality of life) by using standardized tools. Severity of initial head, face and lower-limb injury, intense persistent pain, post-traumatic stress disorder, poor self-assessed quality of life and health status at 3 years were associated with non-return to work on univariate analysis. On multivariate analysis, severity of initial head and lower-limb injury, intense persistent pain at 3 years and post-traumatic stress disorder were significantly associated with non-return to work 3 years following severe roadaccident injury. Post-traumatic stress disorder and chronic pain were essential modifiable medical determinants of non-return to work in the severely injured after a road accident: early adapted management could promote return to work in the severely injured. Improve early adapted treatment of pain and PTSD in the rehabilitation team should help the severely injured return to work following a road accident. 


\section{Introduction}

Road injury designates an accident with at least 1 casualty, on a public thoroughfare, involving at least 1 vehicle. In 2015, there were 56,603 road accidents with injury in France, with 3,461 deaths and 70,802 injured, including 35,000 severely injured. Road accident depend on a range of road and traffic factors that interact with speed and also on the characteristics and behaviour of the drivers using the road, such as age, gender, drink-driving and seatbelt wearing (Fildes 2013). Clear physical relationships lead to higher severity of injury outcomes as speed increases. Apart from the human cost for the individual victims, road accidents have an financial cost including medical and social expenditure for casualties and fatalities (Naumann et al. 2010; Wesson et al. 2014). Prolonged sick leave may have harmful consequences in the form of chronicity and socio-occupational exclusion (Fort et al. 2011). Road traffic accidents may cause psychological diseases. A prospective study of 1534 road-accident casualties aged 1769 years with most minor injuries (61\%), shows one-third of the respondents had a least one of the four psychosocial conditions (post-traumatic stress disorder, phobic travel anxiety, general anxiety, depression) at 3 months (36\%) and $15 \%$ of subjects suffered PTSD at 1 year and $11 \%$ of subjects at 3 years (Mayou and Bryant 2001, 2002).

Road accidents may also impact victims' physical socio-occupational life, particularly the capacity to return to work (Buitenhuis et al. 2009; Fitzharris, Bowman, and Ludlow 2010). Accident-related traumatic injuries often require sick leave while health status recovers. In the study conducted by Mayou and al. most road-accident casualties were working at 3 months(69\%), at 1 year (73\%) and at 3 years(75\%) after the accident (Mayou and Bryant 2001, 2002). 
It has been shown that injury related factors (localization, severity, number of injuries) are major determinants of functional outcome (Holbrook et al. 1999; Vles et al. 2005). A substantial number of major traumas suffer from long term impairments, disabilities and handicaps particularly in severe lesions from head, spine and lower limbs (Currens 2000). Furthermore, the relationship between the severe injuries and the difficult return to work has been established (Currens 2000). Several studies investigated determinants of return to work after major trauma, and identified socio-occupational factors and medical factors (Gross et al. 2010; Clay et al. 2010b). Physical impairment and pain were significantly associated with non-work disability after multiple trauma (Anke et al. 1997). Demographic and injury related factors and social functioning were significant predictors of return to work status after multiple severe injuries (Soberg et al. 2007). Few studies, focused on road-accident casualties (Fort et al. 2011; Hours et al. 2010a) . Improving the chances of return to work of the severely injured road-accident victims requires knowledge about determinants of non-return to work. The objective of the present study was to identify modifiable medical and socio-occupational risk factors for non-return to work in severely injured road-accident victims 3 years after the road accident. 


\section{Materiels and methods}

\subsection{Selection of participants in the ESPARR cohort}

The ESPARR study (Etude de Suivi d'une Population d'Accidentés de la Route dans le Rhône) monitors a prospective cohort of road accident casualties in order to study the short and medium term consequences of the accident. This cohort is a subpopulation of the Rhone Registry of road accident victims, which has been collecting almost exhaustive data on road accidents involving injury in the area since 1995 (Laumon et al. 1997) The inclusion period for the cohort was from October 1, 2004 to July 2006 (Hours et al. 2010a). All road-accident casualties who sought medical care in public or private hospitals in the Rhône administrative area were eligible for inclusion (Hours et al. 2008b). Inclusion criteria comprised:

- having had a road accident involving at least one mechanical means of transport;

- living and having had the accident in the Rhône administrative area (pop. 1.6m);

- $\quad$ having survived the crash;

- $\quad$ and having been a patient in one of the area's hospitals.

Only patients (or their family) who gave consent for follow-up were included in the cohort. Injured people (or a member of their family) were contacted by an interviewer during their stay for care at the hospital. In all, 1,168 subjects aged 16 years over at the time of accident, agreed to participate in the project, forming the ESPARR cohort. Because of the large disproportion between casualties with mild-to-moderate injuries (90\% of cases) and those with severe injuries, inclusion was stratified by maximum injury severity on the Abbreviated Injury Scale (AIS) ("Association for the Advancement of Automotive Medicine (AAAM) . The Abbreviated Injury Scale" 1990; Hours et al. 2008b). This classification standardizes injury data, scoring each lesion from one (minor) to six (fatal). The M.AIS is the maximal AIS score sustained by a casualty. The objective 
was to recruit all accident victims with serious-to-critical injury (M-AIS $\geq 3$ ), and to have half of the series with moderate injury (M-AIS 2) and one in six with minor injury (MAIS 1). The NISS (New Injury Severity Score) is calculated as the sum of the squares of AIS scores for the casualty's three most severe injuries, regardless of body region.

\subsection{Study population}

A total of 773 of the 1,168 working subjects in the ESPARR cohort (age range 16-64 years) were in work at the time of their accident. Amongst the 773 subjects, 224 who had severe injury (M-AIS 3+), constituted the target population. Half of the participants had an educational level below school-leaving certificate (baccalauréat). At the time of the accident, three-quarters were working in the private sector, with permanent contracts

\subsection{Variables and measurement tools}

To collect data on the accident and the previous familial, occupational and health situations, interviewers were present in the emergency units and ran face-to-face interviews with the victim (or family members) after patients have given informed consent (Hours et al. 2008a, [a] 2010). Participants were asked to fill out a 6-month follow-up self-administered questionnaire, sent by post, investigating their opinion of their overall state of health. In case of non-response, a telephone call was made to fill out the questionnaire with the patient. At 1 year and 3 years' post-accident, a neuropsycho-social check-up and medical consultation were offered to victims rated M-AIS $\geq$ 3 or with head lesions rated M-AIS $\geq 2$ (moderate cranial trauma). A questionnaire was filled out with the patient during this consultation; other cohort members were sent the questionnaire by mail for self-administration. In case of postal non-response or refusal of consultation, telephone contact was made (Michaels et al. 2000) 
The variables studied at inclusion and during the post-accident phase were of several types (Hours et al. 2010b) Briefly, for this analysis, the following variables were used:

- sociodemographic at the time of accident: gender, age, educational level, marital status, socio-occupational group assessed by International Standard Classification of Occupations (ISCO-68);

- accident-related: type of road user, type of journey, responsibility in the accident self-assessed by the casualties (Hours et al. 2008b);

- pre-accident diseases;

- initial care: M-AIS by body region (head, face, spine, thorax, abdomen, upper limbs, lower limbs) and New Injury Severity Score (NISS);

- physical sequelae self-assessed by the subjects, three years post-accident

- work-related: physically or psychologically tiring work self-assessed by the casualties, sick leave, and date of return;

- post-traumatic stress disorder (PTSD), assessed at 1 year post accident by a validated French translation of the Post-traumatic Stress disorder Check-List scale (PSCL) (Ventureyra et al. 2002); scores equal to or greater than 44 indicate PTSD;

- Pain was evaluated at 3 years on a visual analogue scale from no pain $(0 \mathrm{~mm})$ to the maximal conceivable pain $(100 \mathrm{~mm})$.

- The perceived quality of life was assessed at 3 years on the World Health Organization Quality of Life Questionnaire-Brief Version (WHOQOL-Bref). This questionnaire has good psychometric properties and good validity (Skevington, Lotfy, and O'Connell 2004). It is composed of 26 questions: 2 independent items assessing quality of life and satisfaction with health, and 24 items exploring 4 dimensions (physical, psychological, social and 
environmental). Responses to each question are on a 5-point Likert scale, quantifying intensity ("not at all" to "extremely"), capacity ("not at all" to "completely"), frequency ("never" to "always") or an assessment ("very dissatisfied" to "very satisfied" or "very poor" to "very good"). Responses are weighted by an algorithm to calculate "profile" scores. We used the transformed scale from 0 to 100 . The highest is the score, the best is the quality of life.

\subsection{Definition of return to work}

In our study, the outcome "return to work", involved 3 situations of return to work within 3 years of the accident

_ working at 1 year but not at 3 years post-accident;

- working at both 1 year and 3 years post-accident;

- Not having returned to work at 1 year but working at 3 years.

\subsection{Statistical analysis}

A descriptive step characterized participants according to sociodemographic data, accident-related data, prior health status, initial care, work-related data, post-traumatic stress disorder, and consequences at 3 years.

Associations between return to work in the 3 years following the accident on the one hand and accident-related and post-accident factors were analyzed on univariate analysis. Frequencies were compared on chi $^{2}$ test and means on Student t-test.

Ratios of event probabilities per case of return to work were studied. As the prevalence of this event was high, odds ratios would not have provided a good estimate of relative risk (RR); a log-linked binomial model was therefore applied, using the PROC 
GENMOD procedure in the SAS statistical package (version 9.3) with the DIST $=$ BINOMIAL and LINK=LOG options.

The binary response of each case of return to work was modeled in three steps:

- Firstly, all independent variables underwent univariate analysis.

- Secondly, multivariate analyses were performed for each dimension: model 1, accident-related factors; model 2, post-accident factors. Variables with p-value $\leq$ 0.1 were included in a multivariate model by a descending procedure; variables with p-value $<0.05$ remained in the model. Due to a positive association between physical sequelae and persistent pain, we chose to drop the variable "physical sequelae" from the multivariate model for post-accident medical factors; the "quality of life" and "health satisfaction" variables were maintained, but quantitative scores on the 4 quality-of-life dimensions (physical, psychological, social and environmental) were not included.

- Thirdly, multivariate analysis was performed with each of the preceding final models.

In case of non-convergence of PROC GENMOD because the maximum likelihood estimate (MLE) lay on the boundary of the parameter space, the SAS COPY macro was used providing a good approximation to the exact maximum likelihood estimates, as well as yielding good estimates of the true population parameters(Deddens, Petersen, and Lei 2003).

\subsection{Ethics and consent}

The study protocol was submitted to and approved by the French Ministry of Research (CCTIRS: Advisory Committee on Information Processing in Material Research in the Field of Health) (CCTIRS Number 04.159). Data collection and analysis were approved 
by the national data protection authority (CNIL: CNIL Number 04-1417). Lastly, only patients who gave written consent for follow-up were included in the cohort. At any time during the follow-up period, subjects were free to cease participation, and, in that case, to be totally withdrawn from the study files and analyses

\section{Results}

\subsection{Descriptive analysis}

141 of the 224 subjects who had severe injury (63\%) answered the both one and three years self-questionnaires and their return-to-work status could be determined. Most of them were men $(80 \%)$ (figure 1$)$. Table 1 shows some of the characteristics of the participants .Half of them were younger than 35 years and were living with a partner at the time of accident. The accident occurred while at work (mission and commute) in $43 \%$ of cases. Almost $80 \%$ of subjects $(n=113)$ returned to work within 3 years.

\subsection{Univariate analysis}

Non-return to work was associated with:

3.2.1. Sociodemographic factors at the time of the accident:

Age, marital status (separated, widowed, divorced Relative Risk [RR] $=3.4$; 95\% Confidence Interval [CI] ,1.3-8.7) (tables 1,5);

\subsubsection{Medical factors at the time of the accident:}

Facial lesion $(\mathrm{RR}=1.9 ; 95 \% \mathrm{CI}, 0.9-3.6)$, severity of head $(\mathrm{RR}=2.9 ; 95 \% \mathrm{CI}$, 1.4-6.2), and lower-limb lesions ( $\mathrm{RR}=2.4 ; 95 \% \mathrm{CI}, 1.0-6.0)$ (Tables 2,5).

\subsubsection{Medical factors at 3 years post-accident:}


Intensity of pain $(\mathrm{RR}=8.86 ; 95 \% \mathrm{CI}, 2.7-28.9), \mathrm{PTSD}(\mathrm{RR}=2.8 ; 95 \% \mathrm{CI}, 1.5-$ 5.4), impaired quality of life $(\mathrm{RR}=4.1 ; 95 \% \mathrm{CI}, 2.2-7.8)$, and health dissatisfaction $(\mathrm{RR}=3.8 ; 95 \% \mathrm{CI}, 1.8-8.2)$ (Tables 3-5). There was no significant interaction between pain at three years and PTSD.

\subsection{Multivariate analysis}

The association between non-return to work at 3 years and head lesion severity $(\mathrm{RR}=7.5 ; 95 \% \mathrm{CI}, 2.8-19.6)$, pain intensity $(\mathrm{RR}=8.3 ; 95 \% \mathrm{CI}, 2.6-26.9)$ and PTSD $(\mathrm{RR}=2.2 ; 95 \% \mathrm{CI}, 1.2-3.7)$ persisted (Table 5).

Pain intensity and PTSD are modifiable factors among factors associated with non-return to work in the severely injured after a road accident.

\section{Discussion}

The present study highlighted the importance of certain social factors (age greater than 45 years, no living with a partner), initial medical factors (severity of initial head, face and lower-limb injury) and post-accident medical factors (intense persistent pain, posttraumatic stress disorder, poor self-assessed quality of life and health status) in determining non-return to work 3 years after severe road injury.

\section{Socio-occupational factors}

In the present study, age greater than 45 years emerged as a risk factor for non-return to work at 3 years, in agreement with the literature (Fort et al. 2011; Pélissier, Fontana, and Chauvin 2014). Disability might be harder to accommodate for patients aged 45 because they may have had incentive to take early medical retirement that a younger patient would not have. Moreover, our findings show that subjects separated, widowed, or divorced are more likely not to return to work at 3 years. Mackenzie found that a 
strong social network was associated with successful return to work after Spinal Cord Injury (E. J. MacKenzie et al. 1987).

The literature highlights an association between low educational level and delayed return to work in the severely injured (Soberg et al. 2007; Clay et al. 2010a). Walker at al., in a prospective cohort study of 1,341 patients with traumatic brain injury, showed that the rate of return to work was greatest for professional/ managerial workers and lowest for manual laborers (Walker et al. 2006). However in our study, there was a nonsignificant trend for manual workers to return to work less often than directors and office workers. The lack of significance for the relation between socio-occupational status and return to work may have been due to sample size and power.

\subsection{Initial medical factors}

Several studies showed that injury severity negatively impacts return to work, in particular after orthopedic trauma (Clay et al. 2010a; Murgatroyd et al. 2016). In this study, there was a significant association between head or lower-limb lesion severity and non-return to work at 3 years, in agreement with the literature (Clay et al. 2010a; Ellen J. MacKenzie et al. 2006; Murgatroyd et al. 2016). Severe lower-limb lesions may entail incapacity hindering mobility and very often requiring work-station adaptation, which can delay return to work. The predominant severe head lesions were craniocerebral: hematoma, hemorrhage, edema, and diffuse axonal lesions (Gadegbeku, NDiaye, and Chiron 2006); these may be accompanied by medical complications such as cognitive disorder, delaying return to work (Annoni and Colombo 2011). The most effective preventive measures to reduce initial lesion severity are those reducing the rate of road injury: speed limits, mandatory helmets for motorcyclists and mandatory seatbelts for motorists (E. J. MacKenzie et al. 2011; Masson 2000). Spinal lesions are often mentioned as entailing elevated risk of difficulty in returning to work (Krause 
2003; Lidal, Huynh, and Biering-Sørensen 2009); the present study, however, found no relation between severity of spinal lesions and non-return to work, perhaps due to small sample size for spinal lesions, whence lack of power.

\subsection{Post-accident medical factors}

\subsubsection{Health perception}

In our study, a good result from the self-assessment of health status had a positive influence on returning to work. Previous studies confirmed the role of illness perception and subjective complaints on the worker's fear of returning to work after a long illness (Dekkers-Sánchez et al. 2012; Øyeflaten, Hysing, and Eriksen 2008). In another study, the roles of the worker's health perception and expectation of recovery in relation to the resumption of work were highlighted (Schultz et al. 2004; Pélissier, Fontana, and Chauvin 2014).

\subsubsection{Quality of life}

Perceived quality of life is a factor in return to work after an accident. In the present study, impaired quality of life in the physical, psychological, social and environmental domains was associated with non-return to work, although not significantly on multivariate analysis. Vestling et al. showed that returning to work after stroke was a major factor for high subjective well-being (Vestling, Tufvesson, and Iwarsson 2003). Mobility issues due to physical or cognitive incapacity may impair quality of life and hinder return to work (Kozlowski et al. 2002; Lidal, Huynh, and Biering-Sørensen 2009).

\subsubsection{PTSD}

PTSD is a common psychological reaction to involvement in road accidents (Matthews 2005). More than three-quarters of the present severely injured subjects showed PTSD during the 3 years following the accident. Zatzick et al. showed that 
PTSD was associated with enduring impairment after traumatic injury (Zatzick et al. 2008). In the present study, PTSD was significantly associated with non-return to work, in agreement with the literature. According to Matthews, survivors with PTSD were found to have significantly less work potential than those without PTSD (Matthews 2005). Moreover, according to Opsteegh et al., pain, if uncontrolled and prolonged, may be an important stressor that could result in the development of PTSD (Opsteegh et al. 2009).

\subsubsection{Pain}

Lower limb injuries are often neglected (compared to other severe lesions) although they are a source of sequelae which make return to work more difficult, notably due to pain. More than half the present subjects complained of moderate to intense pain. Persistent intense pain emerged as a determining factor in non-return to work, in agreement with the literature. A previous study of socio-occupational outcome for roadaccident casualties highlighted the role of persistent pain in delayed return to work (Fort et al. 2011). Moreover, persons with negative pain beliefs were more likely to experience work disability (Ciccone and Just 2001; Clay et al. 2010a). Kovacs et al., studying Spanish low-back pain patients, reported that pain severity was the main determinant of disability, and disability was the main determinant of physical and mental quality of life (Fm et al. 2005). According to Ciccone et al., patients who habitually overpredict pain outcomes and as a result become excessively inactive may be most likely to benefit from rehabilitation programs (Ciccone and Just 2001). Several studies found an association between pain and PTSD (Åhman and Stålnacke 2008; Fishbain et al. 2016), and Duckworth et al. showed that road-accident casualties with PTSD employed inappropriate pain adjustment strategies (Duckworth and Iezzi 2005).

\subsection{Strengths and Limitations}


The strong points of the study were, firstly, to present results of 3 years' follow-up of severely injured ESPARR road-accident cohort members, aged 16 years or older, representative of the Rhône Area Road Accidents Registry population. To our knowledge, no previous studies included a wide range of determinants, using multivariate analysis to select the most relevant factors, in a 3-year prospective cohort of severely injured road-accident victims. Moreover, this study has a good response rate for the severely injured group $(63 \%, \mathrm{n}=141)$, with homogeneous assessment of road accident consequences at systematic intervals. Finally, standardized tools were used to assess initial injury (AIS and ISS), pain (visual analog scale), PTSD (PSCL) and quality of life (WHOQOL-Bref). There nevertheless remain weaknesses related to patients lost to follow-up, who tended to be young, which could lead to overestimating non-return to work in seriously injured casualties. Besides other medical factors that may impact return to work, such as substance use, adherence to medical exercise, and participations in rehabilitation programs could not be included in this study.

\section{Conclusions}

This study underlined that the failure of severely injured road-accident casualties to return to work 3 years after their accident was related to initial head and lower-limb lesion severity but was also related to modifiable medical factors such as persistent moderate to intense pain, and PTSD. Early medical treatment of residual pain and PTSD seems crucial to rehabilitation and return to work for severely injured road-accident victims. Understanding factors that attenuate or exaggerate the disabling effects of chronic pain in the workplace may help to inform policies and interventions to improve return to work. Besen et al. found pain catastrophizing to be a significant mediator for work limitations, which provide a potential target of interventions in programs to prevent work disability (Besen et al. 2017). Matthews et al. showed a significant 
negative influence of PTSD symptoms on work functioning, and underlined the need for regular PTSD symptoms screening in rehabilitation assessment procedures(Matthews and Chinnery 2005). In France, the severely injured are managed in after-care and rehabilitation departments, to minimize the functional, physical, cognitive, psychological and social impact of residual deficits and facilitate integration. Also, it is important that work-related issues should be discussed explicitly in the rehabilitation team to facilitate return to work. An organization, Comète France, brings together medical and rehabilitation physicians, occupational physicians, ergonomists, occupational psychologists and social workers to initiate early management of social and occupational issues while patients are still in the hospital and favor return to work.

\section{Acknowledgments}

The authors would like to thank all those who assisted in the performance of this study: Nadia Baguena, Jean Yves Bar, Amélie Boulanger, Pierrette Charnay, Elodie Paquelet, Stuart Nash and Véronique Sotton for data collection; Laetitia Chossegros and Hélène Tardy,Charlène Tournier, Irène Vergnes for data-base organization, Anne-Marie Bigot, Nathalie Demangel and Geneviève Boissier for subject data-base management; Amina Ndiaye, Blandine Gadegbeku and the Association for the Registry of Road Traffic Casualties in the Rhône Département (ARVAC) for their help in collecting medical data and for making the Registry database available; the Scientific Committee (Daniel Floret, François Chapuis, Jean Michel Mazaux, Jean Louis Martin and Jacques Gaucher); all the hospital staff who accepted the interviewers' presence and referred patients; and the SAMU team who reported their emergency interventions every day. 
This work was supported by the French Ministry of Equipment, Transport Housing, Tourism and SEA (Predit 3 Program "New Knowledge in the Field of Road Safety": $n^{\circ}$ SU0400066), by the National Agency for Research (Program Predit "Safe, reliable and adapted transport" $\mathrm{n}^{\circ}$ ANR-07-TSFA-007-01) and by the French Ministry of Health (Program PCRD 2003: PHRC-N03 and PCRD 2005: N051). The role of the funding sources was in the collection and the analysis of data.

\section{Authors declare no conflicts of interest}




\section{References}

Åhman, Sofia, and Britt-Marie Stålnacke. 2008. "Post-traumatic Stress, Depression, and Anxiety in Patients with Injury-related Chronic Pain : a Pilot Study." Neuropsychiatric Disease and Treatment 4 (6): 1245-49.

Anke, A. G., J. K. Stanghelle, A. Finset, K. S. Roaldsen, J. Pillgram-Larsen, and A. R. Fugl-Meyer. 1997. "Long-term Prevalence of Impairments and Disabilities after Multiple Trauma." The Journal of Trauma 42 (1): 54-61.

Annoni, J.-M., and F. Colombo. 2011. "Troubles cognitifs et comportementaux après lésion cérébrale: impact sur la reprise professionnelle." Revue médicale suisse 7 (293): 944-47.

"Association for the Advancement of Automotive Medicine (AAAM) . The Abbreviated Injury Scale." 1990. De Plaines, II, 60018 USA, 74.

Besen, Elyssa, Brittany Gaines, Steven J. Linton, and William S. Shaw. 2017. "The Role of Pain Catastrophizing as a Mediator in the Work Disability Process Following Acute Low Back Pain." Journal of Applied Biobehavioral Research 1 (22): n/a-n/a. doi:10.1111/jabr.12085.

Buitenhuis, J., De Jong, Peter J, Jan P. C. Jaspers, and J. W. Groothoff. 2009. "Work Disability After Whiplash: A Prospective Cohort Study." Spine 34 (3): 262-67. doi:10.1097/BRS.0b013e3181913d07.

Ciccone, Donald S., and Nancy Just. 2001. "Pain Expectancy and Work Disability in Patients with Acute and Chronic Pain: A Test of the Fear Avoidance Hypothesis." The Journal of Pain 2 (3): 181-94. doi:10.1054/jpai.2001.21591.

Clay, Fiona J., Stuart V. Newstead, Wendy L. Watson, and Roderick J. McClure. 2010a. “Determinants of Return to Work Following Non Life Threatening Acute Orthopaedic Trauma: a Prospective Cohort Study." Journal of Rehabilitation Medicine 42 (2): 162-69. doi:10.2340/16501977-0495.

-- - 2010b. "Determinants of Return to Work Following Non-Life-Threatening Acute Orthopaedic Trauma: A Prospective Cohort Study." Journal of Rehabilitation Medicine 42 (2): 162-69. doi:10.2340/16501977-0495.

Currens, Julie A. Baldry. 2000. "Evaluation of Disability and Handicap Following Injury." Injury 31 (2): 99-106. doi:10.1016/S0020-1383(99)00246-6.

Deddens, J, M Petersen, and Xiudong Lei. 2003. "Estimation of Prevalence Ratos When PROC GENMOD Does Not Converge." Proceedings of the Twenty-height Annual SAS Users Groupinternational Conference Seattle Washington: SAS Institute INC.

Dekkers-Sánchez, Patricia M., Haije Wind, Judith K. Sluiter, and Monique H. W. Frings-Dresen. 2012. "What Factors Are Most Relevant to the Assessment of Work Ability of Employees on Longterm Sick Leave? The Physicians' Perspective." International Archives of Occupational and Environmental Health 86 (5): 509-18. doi:10.1007/s00420-012-0783-3.

Duckworth, Melanie P., and Tony lezzi. 2005. "Chronic Pain and Posttraumatic Stress Symptoms in Litigating Motor Vehicle Accident Victims." Clinical Journal of Pain 21 (3): 251-61.

Fildes, B. 2013. Driver Behavior and Road. Psychology and Policing. https://books.google.fr/books/about/Psychology_and_Policing.html?hl=fr\&id=QgsMvvLspPQC. 
Fishbain, David A., Aditya Pulikal, John E. Lewis, and Jinrun Gao. 2016. "Chronic Pain Types Differ in Their Reported Prevalence of Post -Traumatic Stress Disorder (PTSD) and There Is Consistent Evidence That Chronic Pain Is Associated with PTSD: An Evidence-Based Structured Systematic Review." Pain Medicine (Malden, Mass.), May. doi:10.1093/pm/pnw065.

Fitzharris, Michael, Diana Bowman, and Karinne Ludlow. 2010. "Factors Associated with Return-towork and Health Outcomes Among Survivors of Road Crashes in Victoria." Australian and New Zealand Journal of Public Health 34 (2): 153-59. doi:10.1111/j.1753-6405.2010.00500.x.

Fm, Kovacs, Muriel A, Abriaira V, Medina Jm, Castillo Sanchez Md, and Olabe J. 2005. "The Influence of Fear Avoidance Beliefs on Disability and Quality of Life Is Sparse in Spanish Low Back Pain Patients." Spine 30 (22): E676-82. doi:10.1097/01.brs.0000186468.29359.e4.

Fort, Emmanuel, Emilie Bouffard, Pierrette Charnay, Marlène Bernard, Dominique Boisson, Bernard Laumon, and Martine Hours. 2011. "Return to Work Following Road Accidents: Factors Associated with Late Work Resumption." Journal of Rehabilitation Medicine 43 (4): 283-91. doi:10.2340/16501977-0670.

Gadegbeku, Blandine, A. NDiaye, and M. Chiron. 2006. "Major Impairments in Road Traumatology, Rhône Register, 1996-2003." B.E.H;Institut de Veille Sanitaire. http://invs.santepubliquefrance.fr//beh/2006/36/beh_36_2006.pdf.

Gross, Thomas, Corinna Attenberger, Rolf W. Huegli, and Felix Amsler. 2010. "Factors Associated with Reduced Longer-Term Capacity to Work in Patients after Polytrauma: A Swiss Trauma Center Experience." Journal of the American College of Surgeons 211 (1): 81-91. doi:10.1016/j.jamcollsurg.2010.02.042.

Holbrook, T. L., J. P. Anderson, W. J. Sieber, D. Browner, and D. B. Hoyt. 1999. “Outcome after Major Trauma: 12-month and 18-month Follow-up Results from the Trauma Recovery Project." The Journal of Trauma 46 (5): 765-771; discussion 771-773.

Hours, Martine, Marlène Bernard, Pierrette Charnay, Laetitia Chossegros, Etienne Javouhey, Emmanuel Fort, Dominique Boisson, Pierre-Olivier Sancho, and Bernard Laumon. 2010a. "Functional Outcome after Road-crash Injury: Description of the ESPARR Victims Cohort and 6month Follow-up Results." Accident; Analysis and Prevention 42 (2): 412-21. doi:10.1016/j.aap.2009.09.002.

- - . 2010b. "Functional Outcome after Road-crash Injury: Description of the ESPARR Victims Cohort and 6-month Follow-up Results." Accident; Analysis and Prevention 42 (2): 412-21. doi:10.1016/j.aap.2009.09.002.

Hours, Martine, Emmanuel Fort, Pierrette Charnay, Marlène Bernard, Jean Louis Martin, Dominique Boisson, Pierre-Olivier Sancho, and Bernard Laumon. 2008a. "Diseases, Consumption of Medicines and Responsibility for a Road Crash: A Case-control Study." Accident Analysis and Prevention 5 (40): 1789-96. doi:10.1016/j.aap.2008.06.017.

- - . 2008b. "Diseases, Consumption of Medicines and Responsibility for a Road Crash: A Casecontrol Study." Accident Analysis \& Prevention 40 (5): 1789-96. doi:10.1016/j.aap.2008.06.017.

Kozlowski, O., B. Pollez, A. Thevenon, P. Dhellemmes, and M. Rousseaux. 2002. "Devenir et qualité de vie à trois ans dans une cohorte de patients traumatisés crâniens graves." Annales de réadaptation et de médecine physique 45 (8): 466-73. 
Krause, James S. 2003. "Years to Employment after Spinal Cord Injury." Archives of Physical Medicine and Rehabilitation 84 (9): 1282-89.

Laumon, B., J. Martin, P. Collet, M. Chiron, M. Verney, A. Ndiaye, and I. Vergnes. 1997. “A French Road Accident Trauma Registry : First Results", January. https://www.scienceopen.com/document?vid=aef4a6d5-506f-483d-a74a-3d02ad55b662.

Lidal, Ingeborg Beate, Tuan Khai Huynh, and Fin Biering-Sørensen. 2009. "Return to Work Following Spinal Cord Injury: a Review." Disability and Rehabilitation, July. doi:10.1080/09638280701320839.

MacKenzie, E. J., Jr J A Morris, G. J. Jurkovich, Y. Yasui, B. M. Cushing, A. R. Burgess, B. J. DeLateur, M. P. McAndrew, and M. F. Swiontkowski. 2011. "Return to Work Following Injury: The Role of Economic, Social, and Job-related Factors." American Journal of Public Health, August. doi:10.2105/AJPH.88.11.1630.

MacKenzie, E. J., S. Shapiro, R. T. Smith, J. H. Siegel, M. Moody, and A. Pitt. 1987. "Factors Influencing Return to Work Following Hospitalization for Traumatic Injury." American Journal of Public Health 77 (3): 329.

MacKenzie, Ellen J., Michael J. Bosse, James F. Kellam, Andrew N. Pollak, Lawrence X. Webb, Marc F. Swiontkowski, Douglas G. Smith, et al. 2006. "Early Predictors of Long-term Work Disability after Major Limb Trauma." The Journal of Trauma 61 (3): 688-94. doi:10.1097/01.ta.0000195985.56153.68.

Masson, F. 2000. “Épidémiologie Des Traumatismes Crâniens Graves.” Annales Françaises d'Anesthésie et de Réanimation 19 (4): 261-69. doi:10.1016/S0750-7658(99)00145-8.

Matthews, Lynda R. 2005. "Work Potential of Road Accident Survivors with Post-traumatic Stress Disorder." Behaviour Research and Therapy 43 (4): 475-83.

Matthews, Lynda R., and Darien Chinnery. 2005. "Prediction of Work Functioning Following Accidental Injury: The Contribution of PTSD Symptom Severity and Other Established Risk Factors." International Journal of Psychology 40 (5): 339-48. doi:10.1080/00207590444000320.

Mayou, Richard, and Bridget Bryant. 2001. "Outcome in Consecutive Emergency Department Attenders Following a Road Traffic Accident." The British Journal of Psychiatry : the Journal of Mental Science 179 (December): 528-34. doi:10.1192/bjp.179.6.528.

- - . 2002. "Outcome 3 Years after a Road Traffic Accident." Psychological Medicine 32 (4): 67175.

Michaels, A. J., C. E. Michaels, J. S. Smith, C. H. Moon, C. Peterson, and W. B. Long. 2000. "Outcome from Injury: General Health, Work Status, and Satisfaction 12 Months after Trauma." The Journal of Trauma 48 (5): 841-848; discussion 848-850.

Murgatroyd, Darnel F., lan A. Harris, Yvonne Tran, and Ian D. Cameron. 2016. "Predictors of Return to Work Following Motor Vehicle Related Orthopaedic Trauma." BMC Musculoskeletal Disorders 17 (1): 171. doi:10.1186/s12891-016-1019-6.

Naumann, Rebecca B., Ann M. Dellinger, Eduard Zaloshnja, Bruce A. Lawrence, and Ted R. Miller. 2010. "Incidence and Total Lifetime Costs of Motor Vehicle-Related Fatal and Nonfatal Injury 
by Road User Type, United States, 2005." Traffic Injury Prevention 11 (4): 353-60. doi:10.1080/15389588.2010.486429.

Opsteegh, Lonneke, Heleen A. Reinders-Messelink, Donna Schollier, Johan W. Groothoff, Klaas Postema, Pieter U. Dijkstra, and Corry K. van der Sluis. 2009. "Determinants of Return to Work in Patients with Hand Disorders and Hand Injuries." Journal of Occupational Rehabilitation 19 (3): 245-55. doi:10.1007/s10926-009-9181-4.

$\varnothing y e f l a t e n$, Irene, Mari Hysing, and Hege R. Eriksen. 2008. "Prognostic Factors Associated with Return to Work Following Multidisciplinary Vocational Rehabilitation." Journal of Rehabilitation Medicine 40 (7): 548-54. doi:10.2340/16501977-0202.

Pélissier, C., L. Fontana, and F. Chauvin. 2014. "Factors Influencing Return to Work after Illness in France." Occupational Medicine (Oxford, England) 64 (1): 56-63. doi:10.1093/occmed/kqt142.

Schultz, I.Z, J. Crook, G.R Meloche, J Berkowitz, R Milner, and O.A Zuberbier. 2004. "Psychosocial Factors Predictive of Occupational Low Back Disability: Towards Development of a Return-towork Model." Pain 107 (1): 77-85.

Skevington, S. M., M. Lotfy, and K. A. O'Connell. 2004. “The World Health Organization's WHOQOLBREF Quality of Life Assessment: Psychometric Properties and Results of the International Field Trial A Report from the WHOQOL Group." Quality of Life Research 13 (2): 299-310.

Soberg, Helene Lundgaard, Arnstein Finset, Erik Bautz-Holter, Leiv Sandvik, and Olav Roise. 2007. "Return to Work after Severe Multiple Injuries: a Multidimensional Approach on Status 1 and 2 Years Postinjury." The Journal of Trauma 62 (2): 471-81. doi:10.1097/TA.0b013e31802e95f4.

Ventureyra, Valérie A. G., Sai-Nan Yao, Jean Cottraux, Ivan Note, and Chantal De Mey-Guillard. 2002. "The Validation of the Posttraumatic Stress Disorder Checklist Scale in Posttraumatic Stress Disorder and Nonclinical Subjects." Psychotherapy and Psychosomatics 71 (1): 47-53.

Vestling, Monika, Bertil Tufvesson, and Susanne Iwarsson. 2003. "Indicators for Return to Work after Stroke and the Importance of Work for Subjective Well-being and Life Satisfaction." Journal of Rehabilitation Medicine 35 (3): 127-31.

Vles, Wouter J., Ewout W. Steyerberg, Marie-Louise Essink-Bot, Ed F. van Beeck, J. Dik Meeuwis, and Loek P. H. Leenen. 2005. "Prevalence and Determinants of Disabilities and Return to Work after Major Trauma." The Journal of Trauma 58 (1): 126-35.

Walker, William C., Jennifer H. Marwitz, Jeffrey S. Kreutzer, Tessa Hart, and Thomas A. Novack. 2006. "Occupational Categories and Return to Work after Traumatic Brain Injury: a Multicenter Study." Archives of Physical Medicine and Rehabilitation 87 (12): 1576-82. doi:10.1016/j.apmr.2006.08.335.

Wesson, Hadley K. H., Nonkululeko Boikhutso, Abdulgafoor M. Bachani, Karen J. Hofman, and Adnan A. Hyder. 2014. "The Cost of Injury and Trauma Care in Low- and Middle-income Countries: a Review of Economic Evidence." Health Policy and Planning 29 (6): 795-808. doi:10.1093/heapol/czt064.

Zatzick, Douglas, Gregory J. Jurkovich, Frederick P. Rivara, Jin Wang, Ming-Yu Fan, Jutta Joesch, and Ellen Mackenzie. 2008. "A National US Study of Posttraumatic Stress Disorder, Depression, and Work and Functional Outcomes after Hospitalization for Traumatic Injury." Annals of Surgery 248 (3): 429-37. doi:10.1097/SLA.0b013e318185a6b8. 
Figure 1 : Follow up of the ESPARR adult cohort at 3 years after the accident

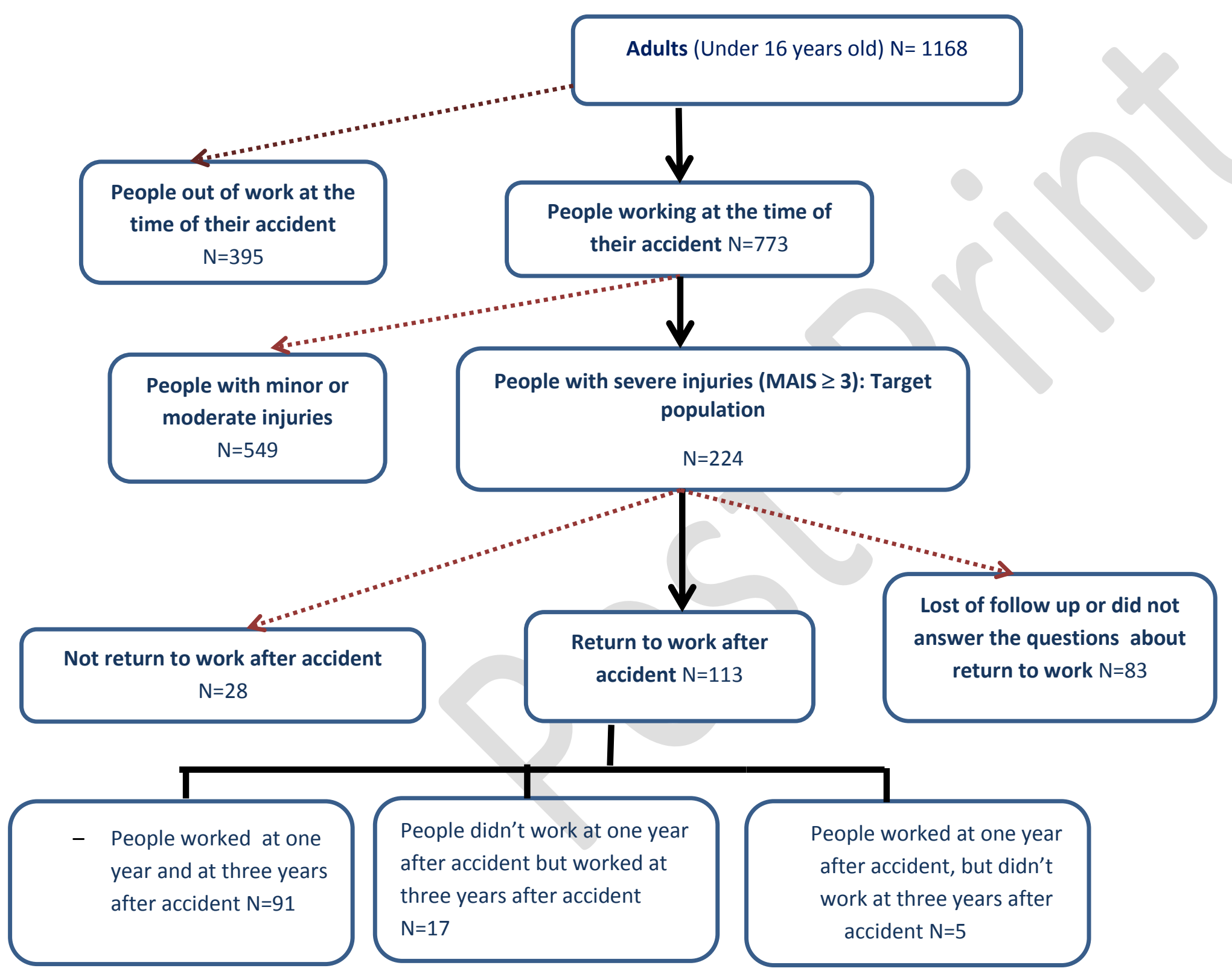


Table 1: Return to work 3 years after road injury according to socio-occupational conditions at the time of the accident

\begin{tabular}{|c|c|c|c|c|c|c|c|c|}
\hline & & \multicolumn{2}{|c|}{ Total } & \multicolumn{2}{|c|}{$\begin{array}{l}\text { Return to } \\
\text { work during } \\
3 \text { years post- } \\
\text { accident }\end{array}$} & \multicolumn{2}{|c|}{$\begin{array}{l}\text { Non-return to } \\
\text { work during } 3 \\
\text { years post- } \\
\text { accident }\end{array}$} & \multirow[t]{2}{*}{$\begin{array}{l}\text { p-value } \\
\left(\text { Chi }^{2}\right. \\
\text { test) }\end{array}$} \\
\hline & & $\mathrm{n}$ & $\%$ & $\mathrm{n}$ & $\%$ & $\mathrm{n}$ & $\%$ & \\
\hline \multirow[t]{2}{*}{ Gender } & Male & 113 & 80.1 & 89 & 78.8 & 24 & 85.7 & NS \\
\hline & Female & 28 & 19.9 & 24 & 21.2 & 4 & 14.3 & \\
\hline \multirow[t]{4}{*}{ Age-group } & $<25$ years & 33 & 23.4 & 30 & 26.6 & 3 & 10.7 & $*$ \\
\hline & {$[25-35[$} & 37 & 26.2 & 31 & 27.4 & 6 & 21.4 & \\
\hline & [35-45[ & 32 & 22.7 & 27 & 23.9 & 5 & 17.9 & \\
\hline & $\geq 45$ years & 39 & 27.7 & 25 & 22.1 & 14 & 50.0 & \\
\hline \multirow[t]{3}{*}{ Marital status } & Single & 52 & 36.9 & 46 & 40.7 & 6 & 21.4 & $*$ \\
\hline & Couple & 71 & 50.4 & 56 & 49.6 & 15 & 53.6 & \\
\hline & $\begin{array}{l}\text { Separated, widowed, } \\
\text { divorced }\end{array}$ & 18 & 12.8 & 11 & 09.7 & 7 & 25.0 & \\
\hline \multirow[t]{5}{*}{ Educational level } & $\begin{array}{l}\text { Level less than the end } \\
\text { Of Secondary school }\end{array}$ & 77 & 55.2 & 58 & 52.3 & 19 & 70.5 & NS \\
\hline & Level equal to the & 16 & 11.6 & 15 & 13.5 & 1 & 03.7 & \\
\hline & End of Secondary school & & & & & & & \\
\hline & Level higher than the & 45 & 32.6 & 38 & 34.2 & 7 & 25.8 & \\
\hline & End of Secondary school & & & & & & & \\
\hline \multirow[t]{5}{*}{ ISCO-68 } & Director, scientific technical & 37 & 26.6 & 32 & 28.9 & 5 & 17.9 & NS \\
\hline & Office worker & 15 & 10.8 & 12 & 10.8 & 3 & 10.7 & \\
\hline & Specialized service sector & 14 & 10.1 & 11 & 09.9 & 3 & 10.7 & \\
\hline & Manual worker & 62 & 44.6 & 47 & 42.3 & 15 & 53.6 & \\
\hline & Sales & 11 & 7.9 & 9 & 08.1 & 2 & 07.1 & \\
\hline \multirow[t]{3}{*}{ Sector } & Private sector & 99 & 74.4 & 79 & 74.5 & 20 & 77.0 & NS \\
\hline & Public sector & 21 & 15.8 & 17 & 16.0 & 3 & 11.5 & \\
\hline & Independent & 13 & 9.7 & 10 & 0.95 & 3 & 11.5 & \\
\hline \multirow[t]{3}{*}{ Type of contract } & Stable & 106 & 76.3 & 85 & 75.22 & 21 & 77.8 & NS \\
\hline & Unstable & 20 & 14.4 & 17 & 15.04 & 3 & 11.1 & \\
\hline & Independent & 13 & 9.3 & 10 & 8.85 & 3 & 11.1 & \\
\hline Physically & Yes & 50 & 48.1 & 42 & 50.0 & 8 & 40.0 & NS \\
\hline Tiring work & No & 54 & 51.9 & 42 & 50.0 & 12 & 60.0 & \\
\hline \multirow{2}{*}{$\begin{array}{l}\text { Psychologically } \\
\text { tiring work }\end{array}$} & Yes & 56 & 53.3 & 7 & 35.0 & 49 & 57.6 & $\nabla$ \\
\hline & No & 49 & 46.7 & 13 & 65.0 & 36 & 42.4 & \\
\hline \multirow[t]{2}{*}{ Type of road } & Pedestrian/roller-skater & 18 & 12.8 & 12 & 10.6 & 6 & 21.4 & NS \\
\hline & 4-wheel vehicle & 44 & 31.2 & 36 & 31.9 & 8 & 28.6 & \\
\hline \multirow[t]{2}{*}{ User } & 2-wheel vehicle & 65 & 46.1 & 53 & 46.9 & 12 & 42.9 & \\
\hline & Bicycle & 14 & 9.9 & 12 & 10.6 & 2 & 07.1 & \\
\hline \multirow[t]{2}{*}{ Type of journey } & Work (mission and & 60 & 43.2 & 46 & 40.7 & 14 & 53.8 & NS \\
\hline & Private & 79 & 56.8 & 67 & 59.3 & 12 & 46.2 & \\
\hline \multirow[t]{3}{*}{ Claimed } & Not responsible & 48 & 40.3 & 37 & 38.1 & 11 & 50.0 & NS \\
\hline & Don't know & 29 & 24.4 & 24 & 24.8 & 5 & 22.7 & \\
\hline & Responsible & 42 & 35.3 & 36 & 37.1 & 6 & 27.3 & \\
\hline Pre-accident & Yes & 32 & 31.4 & 25 & 30.9 & 7 & 33.3 & NS \\
\hline pathology & No & 70 & 68.6 & 56 & 69.1 & 14 & 66.7 & \\
\hline
\end{tabular}

- $\quad \nabla p$-value $<0.1 ;{ }^{*} p<0.05 ;{ }^{* *} p<0.01 ;{ }^{* * *} p<0.001 ; * * * p \leq 10-4$ NS: non significant 


\begin{tabular}{|c|c|c|c|c|c|c|c|c|}
\hline & & \multicolumn{2}{|l|}{ Total } & \multicolumn{2}{|c|}{$\begin{array}{l}\text { At least } 1 \\
\text { return to work } \\
\text { during } 3 \text { years } \\
\text { post-accident }\end{array}$} & \multicolumn{2}{|c|}{$\begin{array}{l}\text { No return to } \\
\text { work during } 3 \\
\text { years post- } \\
\text { accident }\end{array}$} & \multirow[t]{2}{*}{$\begin{array}{l}\text { - } \\
\text { value } \\
\text { (Chi }{ }^{2} \\
\text { test) }\end{array}$} \\
\hline & & $n$ & $\%$ & $n$ & $\%$ & $\mathbf{n}$ & $\%$ & \\
\hline \multirow[t]{2}{*}{ Facial lesion } & Yes & 101 & 71.6 & 85 & 75.2 & 16 & 57.1 & $*$ \\
\hline & No & 40 & 28.4 & 28 & 24.8 & 12 & 42.8 & \\
\hline \multirow[t]{3}{*}{ Head lesion } & No lesion & 66 & 46.8 & 57 & 50.4 & 9 & 32.1 & $* *$ \\
\hline & M-AIS <3 & 45 & 31.9 & 38 & 33.7 & 7 & 25.0 & \\
\hline & $M-A I S \geq 3$ & 30 & 21.3 & 18 & 15.9 & 12 & 42.9 & \\
\hline \multirow[t]{3}{*}{ Spinal lesion } & No lesion & 106 & 80.9 & 88 & 83.0 & 18 & 72.0 & NS \\
\hline & $M-A I S<3$ & 11 & 8.4 & 8 & 07.5 & 3 & 12.0 & \\
\hline & M-AIS $\geq 3$ & 14 & 10.7 & 10 & 09.5 & 4 & 16.0 & \\
\hline \multirow[t]{3}{*}{ Chest lesion } & No lesion & 84 & 61.8 & 70 & 64.2 & 14 & 51.9 & NS \\
\hline & $M-A I S<3$ & 3 & 2.2 & 3 & 02.8 & 0 & 0 & \\
\hline & $M-A I S \geq 3$ & 49 & 36.0 & 36 & 33.0 & 13 & 48.1 & \\
\hline \multirow[t]{3}{*}{ Abdominal } & No lesion & 110 & 78.0 & 91 & 80.5 & 19 & 67.9 & NS \\
\hline & M-AIS <3 & 16 & 11.4 & 12 & 10.6 & 4 & 14.3 & \\
\hline & $M-A I S \geq 3$ & 15 & 10.6 & 10 & 08.9 & 5 & 17.8 & \\
\hline \multirow[t]{3}{*}{ Upper-limb } & No lesion & 61 & 48.8 & 45 & 45.9 & 16 & 59.3 & NS \\
\hline & M-AIS <3 & 22 & 17.6 & 16 & 16.3 & 6 & 22.2 & \\
\hline & M-AIS $\geq 3$ & 42 & 33.6 & 37 & 37.8 & 5 & 18.5 & \\
\hline \multirow[t]{3}{*}{ Lower-limb } & No lesion & 42 & 29.8 & 37 & 32.7 & 5 & 17.9 & $*$ \\
\hline & M-AIS <3 & 30 & 21.3 & 27 & 23.9 & 3 & 10.7 & \\
\hline & M-AIS $\geq 3$ & 69 & 48.9 & 49 & 43.4 & 20 & 71.4 & \\
\hline \multirow[t]{2}{*}{ NISS } & NISS $<16$ & 46 & 27.5 & 41 & 36.3 & 5 & 17.9 & $\nabla$ \\
\hline & NISS $\geq 16$ & 95 & 72.5 & 72 & 64.7 & 23 & 82.1 & \\
\hline
\end{tabular}

$\nabla p$-value $<0.1 ;{ }^{*} p<0.05 ; * * p<0.01 ; * * * p<0.001 ; * * * * 0 \leq 10-4$ NS: non-significant 


\begin{tabular}{|c|c|c|c|c|c|c|c|c|}
\hline & & \multicolumn{2}{|c|}{ Total } & \multicolumn{2}{|c|}{$\begin{array}{l}\text { Return to } \\
\text { work } \\
\text { during } 3 \\
\text { years post- } \\
\text { accident }\end{array}$} & \multicolumn{2}{|c|}{$\begin{array}{l}\text { Non- } \\
\text { return to } \\
\text { work } \\
\text { during } 3 \\
\text { years } \\
\text { post- } \\
\text { accident }\end{array}$} & \multirow[t]{2}{*}{$\begin{array}{l}\text { p-value } \\
\left(\text { Chi }^{2}\right. \\
\text { test) }\end{array}$} \\
\hline & & $\mathrm{n}$ & $\%$ & $n$ & $\%$ & $n$ & $\%$ & \\
\hline \multirow[t]{3}{*}{ Pain } & $\begin{array}{l}\text { Fairly weak, } \\
\text { weak }\end{array}$ & 62 & 43.9 & 59 & 52.2 & 3 & 10.7 & $* * * *$ \\
\hline & Medium & 51 & 36.2 & 38 & 33.6 & 13 & 46.4 & \\
\hline & $\begin{array}{l}\text { Intense, fairly } \\
\text { intense }\end{array}$ & 28 & 19.9 & 16 & 14.2 & 12 & 42.9 & \\
\hline \multirow{2}{*}{$\begin{array}{l}\text { Physical } \\
\text { sequelae }\end{array}$} & Yes & 123 & 88.5 & 96 & 85.7 & 27 & 100 & $* *$ \\
\hline & No & 16 & 11.51 & 16 & 14.3 & 0 & 0 & \\
\hline \multirow[t]{2}{*}{ PTSD } & Yes & 23 & 82.84 & 13 & 12.1 & 10 & 37.0 & $* *$ \\
\hline & No & 111 & 17.16 & 94 & 87.9 & 17 & 63.0 & \\
\hline \multirow{3}{*}{$\begin{array}{l}\text { Quality of } \\
\text { life }\end{array}$} & Poor, very poor & 11 & 7.86 & 4 & 03.6 & 7 & 25.0 & $* * *$ \\
\hline & $\begin{array}{l}\text { Neither good } \\
\text { nor bad }\end{array}$ & 32 & 22.86 & 26 & 23.2 & 6 & 21.4 & \\
\hline & Good, very good & 97 & 69.29 & 82 & 73.2 & 15 & 53.6 & \\
\hline \multirow[t]{3}{*}{$\begin{array}{l}\text { Health } \\
\text { satisfaction }\end{array}$} & $\begin{array}{l}\text { Very } \\
\text { dissatisfied, } \\
\text { dissatisfied }\end{array}$ & 27 & 19.29 & 16 & 14.2 & 11 & 39.3 & $*$ \\
\hline & $\begin{array}{l}\text { Moderately } \\
\text { satisfied }\end{array}$ & 29 & 20.71 & 21 & 18.8 & 8 & 28.6 & \\
\hline & $\begin{array}{l}\text { Satisfied, very } \\
\text { satisfied }\end{array}$ & 84 & 60.00 & 75 & 67.0 & 9 & 32.1 & \\
\hline
\end{tabular}

$\nabla p$-value $<0.1 ;{ }^{*} p<0.05 ;{ }^{* *} p<0.01 ; * * * p<0.001 ; * * * * p \leq 10-4$ NS: non-significant

Table 4: Comparison of mean scores on each quality-of-life dimension according to return to work

$\begin{array}{ll}\text { Non-return to work } & \text { Return to work during } 3 \\ \text { during } 3 \text { years post- } & \text { years post-accident } \\ \text { accident } & \end{array}$

$\begin{array}{lllllll}\mathbf{N} & \mathbf{m} & \text { SD } & \mathbf{N} & \mathbf{m} & \text { SD } & \text { p-value }\end{array}$

(t-test)

\begin{tabular}{llllllll}
\hline Physical, at 3 years & 28 & 49.7 & 20.6 & 112 & 76.9 & 16.9 & $* * * *$ \\
\hline Psychological, at 3 years & 28 & 55.4 & 21.9 & 111 & 70.0 & 14.8 & $* *$ \\
\hline Social, at 3 years & 28 & 65.8 & 20.6 & 110 & 76.2 & 18.6 & $* *$ \\
\hline Environmental, at 3 years & 28 & 65.6 & 14.5 & 112 & 72.3 & 16.4 & $*$ \\
\hline
\end{tabular}

${ }^{*} p<0.05$; $^{* *} p<0.01$; ${ }^{* *} p<0.001 ; * * * * p \leq 10-4 ;$ NS: non-significant;

$m:$ mean ; SD : Standard Deviation 
Table 5: Relations between non-return to work and accident-related and 3-year post-accident factors

\begin{tabular}{|c|c|c|c|c|c|c|c|c|c|c|c|}
\hline \multicolumn{2}{|c|}{$\begin{array}{l}\text { Accident-related factors associated } \\
\text { with non-return to work }\end{array}$} & \multicolumn{2}{|c|}{$\begin{array}{l}\text { Return to } \\
\text { work during } 3 \\
\text { years post- } \\
\text { accident }\end{array}$} & \multicolumn{2}{|c|}{$\begin{array}{l}\text { Non-return to } \\
\text { work during } 3 \\
\text { years post- } \\
\text { accident }\end{array}$} & \multicolumn{2}{|c|}{$\begin{array}{l}\text { Univariate } \\
\text { analysis }\end{array}$} & \multicolumn{2}{|c|}{$\begin{array}{l}\text { Multivariate analysis } \\
\text { (model } 1 \text { ) }\end{array}$} & \multicolumn{2}{|c|}{$\begin{array}{l}\text { Multivariate analysis } \\
\text { (model 3: } \\
\text { multivariate analysis } \\
\text { from final models } 1 \\
\text { and 2) }\end{array}$} \\
\hline & & $\mathrm{n}$ & $\%$ & $\mathrm{n}$ & $\%$ & $\mathrm{RR}$ & $95 \% \mathrm{Cl}$ & $\mathrm{RR}$ & $95 \% \mathrm{Cl}$ & $\mathrm{RR}$ & $95 \% \mathrm{Cl}$ \\
\hline \multirow[t]{2}{*}{ Gender } & Female & 89 & 78.8 & 24 & 21.2 & 1 & & / & / & / & / \\
\hline & Male & 24 & 85.7 & 4 & 14.3 & 1.5 & $0.6-3.9$ & / & / & / & / \\
\hline \multirow[t]{4}{*}{ Age-group } & $<25$ yrs & 30 & 90.9 & 3 & 9.1 & 1 & & / & / & / & / \\
\hline & {$[25-35[$} & 31 & 83.8 & 6 & 16.2 & 1.7 & $0.4-6.6$ & / & / & / & / \\
\hline & {$[35-45[$} & 27 & 84.4 & 5 & 15.6 & 3.9 & $\begin{array}{l}1.2- \\
12.6\end{array}$ & I & I & / & / \\
\hline & $\geq 45$ yrs & 25 & 64.1 & 14 & 35.9 & 1.8 & $0.5-6.6$ & l & / & / & / \\
\hline \multirow[t]{3}{*}{ Marital status } & Single & 46 & 88.5 & 6 & 11.5 & 1 & & / & / & / & / \\
\hline & Couple & 56 & 78.9 & 15 & 21.1 & 1.8 & $0.8-4.4$ & / & / & / & / \\
\hline & $\begin{array}{l}\text { Separated, } \\
\text { widowed, } \\
\text { divorced }\end{array}$ & 11 & 61.1 & 7 & 38.9 & 3.4 & $1.3-8.7$ & / & / & / & / \\
\hline \multirow[t]{2}{*}{ Facial lesions } & No & 85 & 84.2 & 16 & 15.8 & 1 & & / & / & / & / \\
\hline & Yes & 28 & 70.0 & 12 & 30.0 & 1.9 & $\begin{array}{l}0.9- \\
3.63\end{array}$ & / & / & / & / \\
\hline \multirow[t]{3}{*}{ Head lesion } & No lesion & 57 & 86.4 & 9 & 13.6 & 1 & & $\begin{array}{l}1 * * * \\
*\end{array}$ & & $1 * * *$ & \\
\hline & M-AIS <3 & 38 & 84.4 & 7 & 15.6 & 1.1 & $0.5-2.8$ & 1.6 & $0.5-5.5$ & 1.4 & $0.7-2.8$ \\
\hline & $M-A I S \geq 3$ & 18 & 60.0 & 12 & 40.0 & 2.9 & $1.4-6.2$ & 7.5 & $2.8-19.6$ & 2.69 & $1.6-4.5$ \\
\hline \multirow{3}{*}{$\begin{array}{l}\text { Lower-limb } \\
\text { lesion }\end{array}$} & No lesion & 37 & 88.1 & 5 & 11.9 & 1 & & $1 *$ & & $1 * *$ & \\
\hline & M-AIS <3 & 27 & 90.0 & 3 & 10.0 & 0.8 & $0.2-3.2$ & 0.9 & $0.2-3.3$ & 0.87 & $0.3-2.6$ \\
\hline & $M-A I S \geq 3$ & 49 & 71.0 & 20 & 29.0 & 2.4 & $\begin{array}{l}0.98- \\
6.0\end{array}$ & 2.4 & $1.0-5.8$ & 1.9 & $1.2-3.0$ \\
\hline \multirow{2}{*}{\multicolumn{2}{|c|}{$\begin{array}{l}\text { Post-accident factors associated } \\
\text { with non-return to work }\end{array}$}} & \multicolumn{2}{|c|}{$\begin{array}{l}\text { At least } 1 \\
\text { return to } \\
\text { work }\end{array}$} & \multicolumn{2}{|c|}{$\begin{array}{l}\text { Non-return to } \\
\text { work }\end{array}$} & \multicolumn{2}{|c|}{$\begin{array}{l}\text { Univariate } \\
\text { analysis }\end{array}$} & \multicolumn{2}{|c|}{$\begin{array}{l}\text { Multivariate analysis } \\
\text { (model } 2 \text { ) }\end{array}$} & & \\
\hline & & $n$ & $\%$ & $\mathrm{n}$ & $\%$ & $\mathrm{RR}$ & $195 \% \mathrm{Cl}$ & $\mathrm{RR}$ & $95 \% \mathrm{Cl}$ & & \\
\hline \multirow[t]{3}{*}{ Pain } & $\begin{array}{l}\text { Fairly weak, } \\
\text { weak }\end{array}$ & 59 & 95.2 & 3 & 4.8 & 1 & & $1 * * *$ & & $1 * * *$ & \\
\hline & Medium & 38 & 74.5 & 13 & 25.5 & $\begin{array}{l}5.2 \\
7\end{array}$ & $\begin{array}{l}1.59- \\
17.48\end{array}$ & 4.1 & $1.2-13.7$ & 2.8 & $0.9-8.9$ \\
\hline & $\begin{array}{l}\text { Intense, fairly } \\
\text { intense }\end{array}$ & 16 & 57.1 & 12 & 42.9 & $\begin{array}{l}8.8 \\
6\end{array}$ & $\begin{array}{l}2.71- \\
28.93\end{array}$ & 8.3 & $2.6-26.9$ & 6.5 & $2.2-18.6$ \\
\hline \multirow[t]{2}{*}{ PTSD } & No & 94 & 84.7 & 17 & 15.3 & 1 & & $1 * *$ & & $1 * *$ & \\
\hline & Yes & 13 & 56.5 & 10 & 43.5 & 2.8 & $1.5-5.4$ & 2.2 & $1.2-3.7$ & 1.9 & $1.2-2.8$ \\
\hline \multirow[t]{3}{*}{ Quality of life } & $\begin{array}{l}\text { Poor, very } \\
\text { poor }\end{array}$ & 4 & 36.4 & 7 & 63.6 & 4.1 & $2.2-7.8$ & / & / & / & / \\
\hline & $\begin{array}{l}\text { Neither good } \\
\text { nor bad }\end{array}$ & 26 & 81.2 & 6 & 18.8 & 1.2 & $\begin{array}{l}0.51- \\
2.9\end{array}$ & / & / & / & / \\
\hline & $\begin{array}{l}\text { Good, very } \\
\text { good }\end{array}$ & 82 & 84.5 & 15 & 15.5 & 1 & & / & / & / & / \\
\hline \multirow[t]{3}{*}{$\begin{array}{l}\text { Health } \\
\text { satisfaction }\end{array}$} & $\begin{array}{l}\text { Very } \\
\text { dissatisfied, } \\
\text { dissatisfied }\end{array}$ & 16 & 59.3 & 11 & 40.7 & 3.8 & $1.8-8.2$ & / & I & / & / \\
\hline & $\begin{array}{l}\text { Moderately } \\
\text { satisfied }\end{array}$ & 21 & 72.4 & 8 & 27.6 & 2.6 & $1.1-6.0$ & / & / & / & / \\
\hline & $\begin{array}{l}\text { Satisfied, very } \\
\text { satisfied }\end{array}$ & 75 & 89.3 & 9 & 10.7 & 1 & & / & / & / & / \\
\hline
\end{tabular}

